\title{
PATHOGENIC AND PHYLOGENETIC FEATURES OF 2 MULTIRESISTANT PSEUDOMONAS AERUGINOSA STRAINS ORIGINATED FROM REMEDIATED SITES
}

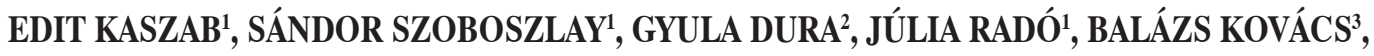 \\ and BALÁZS KRISZT ${ }^{1}$
}

${ }^{1}$ Szent István University, Gödöllo”, Hungary

Department of Environmental Safety and Ecotoxicology

${ }^{2}$ National Institute of Environmental Health, Budapest, Hungary

${ }^{3}$ Szent István University, Gödöllo”, Hungary

Department of Aquaculture

\begin{abstract}
Objectives: To evaluate the possible occupational hazard of environmental strains of opportunistic Pseudomonas aeruginosa on hydrocarbon contaminated sites during remediation, 2 multidrugresistant isolates originating from environmental (soil and groundwater) samples were examined. Material and Methods: Antibiotic resistance profiles of the examined 2 strains were determined by Etest ${ }^{\circledR}$ against 20 different agents. Virulence investigations included the hemolytic activity test, the detection of virulence-related gene sequences such as exo $A$, exo $U$, exoS, exoY, exoT and the determination of intraperitoneal $\mathrm{LD}_{50}$ (the lethal dose, $50 \%$ ) values in a mouse model. The hydrocarbon-degrading ability was evaluated in a gravimetric experiment, in vitro. The phylogenetic relationship of the isolates was investigated with a multilocus sequence typing scheme. Results: Multidrug resistant environmental strains of $P$. aeruginosa are strongly related to isolates that have proven effects on the infection of patients who suffer from cystic fibrosis, have a notable hemolytic activity, carry important virulence markers (exoS or exoU, respectively) and retain their hydrocarbon degradation ability $(87.4 \%$ and $62.8 \%$ hydrocarbon degradation rate, respectively). Conclusions: Pseudomonas aeruginosa presumably raise considerable concerns for human health in the environment, already well known among nosocomial isolates, and the application of environmental strains of this species for environmental purposes is questionable.
\end{abstract}

Key words:

Pseudomonas aeruginosa, Pathogenicity, MLST, Antibiotic resistance, Hydrocarbon degradation, Remediation

\section{INTRODUCTION}

The practice of environmental protection often applies biotechnology for the elimination of various contaminants such as hydrocarbons. However, the widespread application of biotechnological processes requires not only the effectiveness of these methods, but to keep occupational hazards, public health concerns and environmental risks on an acceptable level [1]. Despite these requirements, we can still

This work was supported by the Research Centre of Excellence, project No. 9878/2015/FEKUT. Project manager: Prof. Katalin Posta, D.Sc.

Received: May 6, 2015. Accepted: July 8, 2015.

Corresponding author: S. Szoboszlay, Szent István University, Department of Environmental Safety and Ecotoxicology, Páter Károly 1, H-2100 Gödöllő, Hungary (e-mail: szoboszlay.sandor@mkk.szie.hu). 
find examples of the application of unidentified [2], or opportunistic microorganisms [3] for bioremediation purposes, such as Pseudomonas aeruginosa, a Gram-negative, rod shaped bacterium that is widely known as a nosocomial pathogen with serious concerns for human health [4,5].

With respect to its wide catabolic potential [6] and ubiquitous features, environmental strains of $P$. aeruginosa are commonly applied for the remediation of inorganic [7] and organic [8] contaminants that possibly lead to its increasing influence on the microbial ecosystem of remediated sites. The occupational and public health concerns of this practice are still unclear, since the examined features of a strain applied for bioremediation purposes usually don't overlap with clinically important characteristics. Some evidence suggests that environmental isolates of $P$. aeruginosa species are able to show multidrug resistant features [9] and to form biofilms [10], carry several virulence markers [11] but to give a more comprehensive estimation, phylogenetic investigations are proposed.

Phylogenetic characterization (such as pulsed-field gel electrophoresis (PFGE), random amplification of polymorphic DNA (RAPD), multilocus sequence typing (MLST) profiling) of $P$. aeruginosa is increasingly applied for the evaluation of genetic relations among strains isolated from various environments [12].

The recent opinion suggests that $P$. aeruginosa species exhibits a nonclonal epidemic population structure, where clinical isolates cannot be distinguished from environmental strains [13]. As an evidence of the strong connection between clinical and environmental strains, it has been concluded that while major clonal strains of $P$. aeruginosa isolated from cystic fibrosis (CF) patients are presumably spread person-to-person, unique and minor clonal strains (that are responsible for the minority of $P$. aeruginosa infection of CF patients) are acquired from natural environmental sources [12].

Moreover, in some cases $P$. aeruginosa infections such as community-acquired pneumonia (CAP) can occur outside the hospital settings without any clear predisposing factor [14] that emphasizes the increasing importance of environmental strains.

The comparison of phylogenetic profiling with additional features such as serotyping, genotyping and antibiotic resistance can help us to see the major factors playing a role in the evolutionary trends of environmental $P$. aeruginosa [13]. Considering the possible occupational hazards on bioremediated sites, another urging issue is to clarify the direct concerns for human health of these environmental strains. Testing of animals is still the most reliable way to give information on infectious, invasive and toxic features of these strains.

Therefore, the main aims of this paper have been to evaluate the phylogenetic positions of 2 multidrug resistant P. aeruginosa strains (P43 and $\mathrm{P} 69$ ) isolated from hydrocarbon contaminated natural environments with MLST profiling, to give a complex evaluation of MLST data complemented with several virulence markers (hemolytic activity, and the presence of exo $A$, exoU, exoS, exoT, exoY encoding gene sequences) and to examine in vivo virulence with the determination of $\mathrm{LD}_{50}$ (the lethal dose, 50\%) values in an intraperitoneal mouse model. As additional information, the hydrocarbon degradation abilities of the isolated strains have also been determined.

\section{MATERIAL AND METHODS \\ Sampling}

The examined strains of $P$. aeruginosa (strain collection signs P43 and P69) were isolated from environmental samples of 2 hydrocarbon contaminated sites located in Hungary, where soil and groundwater were periodically monitored. The main properties of the examined contaminated sites and samples are summarized in the Table 1. Soil and groundwater samples were taken in accordance with the relevant Hungarian Standards [15,16] under aseptic conditions. The isolated $P$. aeruginosa strains are presumably the members of indigenous microbiota and were able 
Table 1. The main properties of hydrocarbon contaminated sites examined for the detection of P. aeruginosa species

\begin{tabular}{|c|c|c|c|c|c|c|c|}
\hline Site & $\begin{array}{c}\text { Aliphatic } \\
\text { hydrocarbon } \\
\text { concentrations } \\
\text { of samples } \\
(\text { range }) \\
{[\mu \mathrm{g} /]^{* *}}\end{array}$ & $\begin{array}{l}\text { Remediation } \\
\text { process }\end{array}$ & $\begin{array}{l}\text { Type of } \\
\text { sample }\end{array}$ & $\begin{array}{l}\text { Samples } \\
{[\mathrm{n}]}\end{array}$ & $\begin{array}{c}\text { P. aeruginosa } \\
\text { isolates*** } \\
\text { [n] }\end{array}$ & $\begin{array}{l}\text { Multidrug } \\
\text { resistant } \\
\text { P. aeruginosa } \\
\text { isolates } \\
\text { [n] }\end{array}$ & $\begin{array}{l}\text { Designation } \\
\text { of multidrug } \\
\text { resistant } \\
\text { P. aeruginosa } \\
\text { strains }\end{array}$ \\
\hline $\begin{array}{l}\text { Ópusztaszer, crude oil } \\
\text { pipeline break* }\end{array}$ & $<50-8500$ & $\begin{array}{l}\text { bioremediation, } \\
\text { monitoring }\end{array}$ & $\begin{array}{l}\text { groundwater } \\
\text { and soil }\end{array}$ & 26 & 3 & 1 & $\mathrm{P} 43^{*}$ \\
\hline $\begin{array}{l}\text { Nagyszénás, crude } \\
\text { condensate pipeline } \\
\text { break* }\end{array}$ & $<50-3630$ & $\begin{array}{l}\text { excavation, } \\
\text { monitoring }\end{array}$ & $\begin{array}{l}\text { groundwater } \\
\text { and soil }\end{array}$ & 3 & 2 & 1 & $\mathrm{P} 69^{*}$ \\
\hline
\end{tabular}

* Environmental sites and their isolates were included in a previous study [9].

** Aliphatic fractions (C5-C40) were determined in accordance with Hungarian and International Standards (ISO) [17].

*** In accordance with Hungarian Standard [18].

to reach detectable cell counts by the way of their ability to adapt to hydrocarbon contamination.

\section{Isolation and identification of $P$. aeruginosa}

Isolation, identification and enumeration of $P$. aeruginosa species followed the protocol of the relevant Hungarian Standard [18] with most probable number (MPN) enumeration on selective and differential media. The identification was confirmed with the PCR for the detection of species specific variable regions $\mathrm{V} 2$ and V8 of 16S rDNA [19]. The preparation of DNA was done with the FastDNA ${ }^{\mathrm{TM}}$ kit (Qbiogene 6540-400) following the manufacturer's instructions. Primer sequences were F: 5'-GGGGGATCTTCGGACCTCA-3' and R: 5'-TCCTTAGAGTGCCCACCCG-3', reaction parameters were $95^{\circ} \mathrm{C}, 2 \mathrm{~min}, 25 \times\left(94^{\circ} \mathrm{C}, 25 \mathrm{~s} ; 58^{\circ} \mathrm{C}, 40 \mathrm{~s}\right.$; $\left.72^{\circ} \mathrm{C}, 40 \mathrm{~s}\right) 72^{\circ} \mathrm{C}, 1 \mathrm{~min}$.

\section{Antibiotic resistance}

Multidrug resistant features of environmental $P$. aeruginosa strains P43 and P69 were presumed on the basis of a previously published investigation [9]. In the present work, the range of the examined antibiotics was supplemented with 10 further antibiotic agents. Minimal Inhibitory
Concentrations (MICs) were determined by Etest (AbBiodisk, Solna, Sweden). Altogether 20 agents of 5 classes were examined, out of which 10 are the first choice for clinical therapy of $P$. aeruginosa. The implementation and evaluation were based on the recommendations of the Clinical Laboratory Standards Institute [20,21] and the instructions of the manufacturer (AbBiodisk). Pseudomonas aeruginosa ATCC 27853 was the reference strain. Multidrug resistance was concluded in the case of simultaneous resistance against 2 or more classes of the examined antibiotics [22].

\section{Multilocus sequence typing (MLST)}

Phylogenetic investigation was based on the multilocus sequence typing scheme with the detection and sequencing of 7 housekeeping genes and followed the recommended instructions [23,24].

Primer sequences of the polymerase chain reaction (PCR) based detection are detailed in the Table 2. Reaction parameters were $98^{\circ} \mathrm{C}, 3 \mathrm{~min}, 30 \times\left(95^{\circ} \mathrm{C}, 1 \mathrm{~min} ; 55^{\circ} \mathrm{C}\right.$, $\left.1 \mathrm{~min} ; 72^{\circ} \mathrm{C}, 1 \mathrm{~min}\right) 72^{\circ} \mathrm{C}, 10 \mathrm{~min}$. Amplicons were purified with the MinElute UF PCR Purification Kit (Qiagen) in accordance with the manufacturer's instructions. Nucleotide sequences were determined with the BigDye Terminator (version 3.1) Cycle Sequencing Ready Reaction Kit 
using the following parameters: $96^{\circ} \mathrm{C}, 1 \mathrm{~min}, 30 \times\left(95^{\circ} \mathrm{C}\right.$, $\left.10 \mathrm{~s} ; 51^{\circ} \mathrm{C}, 5 \mathrm{~s} ; 60^{\circ} \mathrm{C}, 2 \mathrm{~min}\right)$. Unincorporated dye terminators were removed with $95 \%$ ethanol precipitation, and reaction products were separated with the ABI Genetic Analyzer Model 3100 (Applied Biosystems). Sequences were assembled by DNA Baser (version 3.0) (Heracle BioSoft). Allelic profiles and sequence types (STs) were determined as it was recommended [25].

\section{Virulence markers}

The examined virulence markers were hemolytic activity on Columbia Blutagar (Heipha Diagnostica) with incubation parameters recommended by the manufacturer $\left(37^{\circ} \mathrm{C}\right.$, $22 \mathrm{~h}$ ), and the detection of toxic protein encoding gene sequences (exo $A, \operatorname{exo} S$, exoT, exoY and exoU) that play primary roles in the pathogenesis of $P$. aeruginosa [26]. The presence of virulence genes was confirmed with the PCR. The applied primer pairs are summarized in the Table 3 , reaction conditions were $95^{\circ} \mathrm{C}, 2 \mathrm{~min}, 30 \times\left(94^{\circ} \mathrm{C}, 1 \mathrm{~min} ; 68^{\circ} \mathrm{C}\right.$, $\left.1 \mathrm{~min} ; 72^{\circ} \mathrm{C}, 1 \mathrm{~min}\right) 72^{\circ} \mathrm{C}, 7 \mathrm{~min}$ in the case of exo $A$ [27] and $94^{\circ} \mathrm{C}, 2 \mathrm{~min}, 36 \times\left(94^{\circ} \mathrm{C}, 30 \mathrm{~s} ; 58^{\circ} \mathrm{C}, 30 \mathrm{~s} ; 68^{\circ} \mathrm{C}, 1 \mathrm{~min}\right) 68^{\circ} \mathrm{C}$, $7 \mathrm{~min}$ in the case of exoS, exoT, exoY and exoU [28].

\section{In vivo virulence investigations in a mouse model}

Investigations on in vivo virulence of the environmental strains were conducted at the Experimental Center of the Central Agricultural Office (Gödöllő, Hungary) in accordance with the relevant national and

Table 2. Primer sequences for the amplification and sequencing of housekeeping genes in the case of $P$. aeruginosa

\begin{tabular}{|c|c|c|c|c|}
\hline Genes & $\begin{array}{l}\text { Primer sequences for amplification } \\
\text { (5' to 3') }\end{array}$ & $\begin{array}{l}\text { Amplicon size } \\
\text { [bp] }\end{array}$ & $\begin{array}{l}\text { Primer sequences for sequencing } \\
\text { (5' to 3') }\end{array}$ & $\begin{array}{c}\text { Amplicon size } \\
\text { [bp] }\end{array}$ \\
\hline \multicolumn{5}{|l|}{$\operatorname{acs} A$} \\
\hline & F: ACCTGGTGTACGCCT CGCTGAC & 842 & F: GCCACACCTACATCGTCTAT & 390 \\
\hline & R: GACATAGATGCCCTGCCCCTTGAT & & R: GTGGACAACCTCGGCAACCT & \\
\hline \multicolumn{5}{|l|}{$\operatorname{aroE}$} \\
\hline & F: TGGGGC TATGACTGGAAACC & 825 & F: ATGTCACCGTGCCGTTCAAG & 495 \\
\hline & R: TAACCCGGTTTTGTGATTCCTACA & & R: TGAAGGCAGTCGGTTCCTTG & \\
\hline \multicolumn{5}{|l|}{ guaA } \\
\hline & F: CGGCCTCGACGTGTGGATGA & 940 & F: AGGTCGGTTCCTCCAAGGTC & 372 \\
\hline & R: GAACGCCTGGCTGGTCTTGTGGTA & & R: TCAAGTCGCACCACAACGTC & \\
\hline mutL & F: CCAGATCGCCGCCGGTGAGGTG & 940 & F: AGAAGACCGAGTTCGACCAT & 441 \\
\hline & R: CAGGGTGCCATAGAGGAAGTC & & R: ATGACTTCCTCTATGGCACC & \\
\hline \multicolumn{5}{|l|}{ пио D } \\
\hline & F: ACCGCCACCCGTACT & 1042 & F: ACGGCGAGAACGAGGACTAC & 366 \\
\hline & R: TCTCGCCCATCTTGACCA & & R: TTCACCTTCACCGACCGCCA & \\
\hline \multicolumn{5}{|l|}{ pps $A$} \\
\hline & F: GGTCGCTCGGTCAAGGTAGTGG & 989 & F: GGTGACGACGGCAAGCTGTA & 369 \\
\hline & R: GGGTTCTCTTCTTCCGGCTCGTA & & R: TCCTGTGCCGAAGGCGATAC & \\
\hline \multicolumn{5}{|l|}{$\operatorname{trp} E$} \\
\hline & F: GCGGCCCAGGGTCGTGAG & 811 & F: TTCAACTTCGGCGACTTCC & 441 \\
\hline & R: CCCGGCGCTTGTTGATGGTT & & R: GGTGTCCATGTTGCCGTTCC & \\
\hline
\end{tabular}

F - forward; $\mathrm{R}$ - reverse; bp - base pairs. 
Table 3. Primer sequences used for the virulence investigations of environmental P. aeruginosa

\begin{tabular}{|c|c|c|c|}
\hline Genes & $\begin{array}{l}\text { Primer sequences for amplification } \\
\qquad\left(5^{\prime} \text { to 3') }\right.\end{array}$ & $\begin{array}{c}\text { Amplicon } \\
\text { size } \\
{[b p]}\end{array}$ & Specification \\
\hline \multicolumn{4}{|l|}{ exoA } \\
\hline & F: AAC CAG CTC AGC CAC ATG TC & 396 & detection of exotoxin A encoding gene sequence \\
\hline & R: CGC TGG CCC ATT CGC TCC AGC GCT & & \\
\hline \multicolumn{4}{|l|}{$\operatorname{exos}$} \\
\hline & F: GCG AGG TCA GCA GAG TAT CG & 118 & detection of exotoxin $\mathrm{S}$ encoding gene sequence \\
\hline & R: TTC GGC GTC ACT GTG GAT GC & & \\
\hline \multicolumn{4}{|l|}{$\operatorname{exoT}$} \\
\hline & F: AAT CGC CGT CCA ACT GCA TGC G & 152 & detection of exotoxin $\mathrm{T}$ encoding gene sequence \\
\hline & R: TGT TCG CCG AGG TAC TGC TC & & \\
\hline \multicolumn{4}{|l|}{$\operatorname{exo} Y$} \\
\hline & F: CGG ATT CTA TGG CAG GGA GG & 289 & detection of exotoxin $\mathrm{Y}$ encoding gene sequence \\
\hline & R: GCC CTT GAT GCA CTC GAC CA & & \\
\hline \multicolumn{4}{|l|}{$\operatorname{exo} U$} \\
\hline & F: CCG TTG TGG TGC CGT TGA AG & 134 & detection of exotoxin $\mathrm{U}$ encoding gene sequence \\
\hline & R: CCA GAT GTT CAC CGA CTC GC & & \\
\hline
\end{tabular}

Abbreviations as in Table 2.

international regulations on animal experiments and the Organisation for Economic Co-operation and Development (OECD) guidelines [29]. Test animals were NMRI line, Specific Pathogen Free (SPF), female albino mice with 18.9-23 g body weight (Charles River Hungary Ltd.), that were randomly separated into groups of 5. Care was given under usual circumstances with ad libitum watering, VRF-1 mouse chow (Charles River Hungary Ltd.) and an ambient temperature of $22 \pm 3^{\circ} \mathrm{C}$.

Growth conditions of the examined bacterial strains were based on the recommended instructions [30,31]. The investigated multidrug resistant environmental isolates of $P$. aeruginosa (P43 and P69) were spread on tryptic soy agar (CASO, Merck 105458) and were incubated in $37^{\circ} \mathrm{C}$ for $18 \mathrm{~h}$. After incubation, the bacterial suspensions of identical colonies were prepared in physiological saline $(0.85 \%)$, with the turbidity equivalent to 0.5 McFarland (bioMérieux), and were serially diluted to reach the experimental concentrations.
The intraperitoneal injection of mice groups was prepared with $0.2 \mathrm{ml}$ of bacterial suspensions of $P$. aerugino$s a$ strains $\mathrm{P} 43$ and $\mathrm{P} 69$. The magnitudes of test concentrations were $10^{3}, 10^{5}$ and $10^{7}$ colony forming units (CFU) per $1 \mathrm{ml}$, respectively; the exact $\mathrm{CFU}$ values were determined with agar plate count method. The negative control was a non-inoculated test group. Based on the scientific literature, the applied concentrations were applicable for the determination of lethal doses of $P$. aeruginosa species [32], but were low enough to differentiate the pathogenic effect from non-specific immune responses.

After experimental infection, the clinical symptoms, such as general condition, behavior, movement coordination, disorders in the nervous system and body weight were documented in the 1st and 4th $\mathrm{h}$ and then every $24 \mathrm{~h}$ for 14 days.

At the end of the experiment, test animals were sacrificed to examine macroscopic changes of gastro-intestinal tract, cardiovascular system, lungs, liver, lien and kidneys. 
The chance of septicaemia was checked with surface spread plate method of blood, originated from heart puncture, on cetrimide agar $\left(37^{\circ} \mathrm{C}, 24 \mathrm{~h}\right)$. The lethal dose, $50 \%$ values were determined in the basis of Miller-Tainter method [33].

\section{Hydrocarbon degradation ability}

The hydrocarbon decomposing ability was determined with a simple, semiquantitative gravimetry measurement using an inoculated mineral medium containing $2 \mathrm{ml}$ of a 3:2 mixture of diesel oil and crude oil. After $120 \mathrm{~h}$ incubation, residual hydrocarbon compounds were recovered with chloroform/petroleum ether extraction following the previously described protocol [34] and were compared to a non-inoculated control incubated under the same conditions.

\section{RESULTS}

The microbial properties of the examined samples are summarized in the Table 4 and the characteristic features of the isolated environmental strains of $P$. aeruginosa, such as: MLST profiles, sequence types (STs), antibiotic resistance and virulence features are shown in the Table 5.

\section{The main properties}

\section{of the examined environmental strains}

The comparison of total bacterial cell counts and the MPN numbers of hydrocarbon degrading bacteria and $P$. aeruginosa of groundwater samples suggests that the examined species is able to reach a considerable rate among the sampled environmental microbiotas (Table 4). Therefore, we can assume that P. aeruginosa speciesis a notable constituent of the microbial community in the examined hydrocarbon contaminated samples.

\section{Hydrocarbon degradation ability}

Based on our investigations, both of the examined environmental strains are able to use hydrocarbon compounds as a solo carbon source and are able to degrade dieselcrude oil components at $87.4 \%$ (P43) and 62.8\% (P69) efficiency. As these results suggest, the indigenous strains of $P$. aeruginosa are able to adapt to hydrocarbon contaminations and to reach outstanding hydrocarbon degradation rates in vitro.

\section{Multilocus sequence typing (MLST)}

The application of an MLST scheme on environmental $P$. aeruginosa isolates led to the detection of 2 known sequence types, ST253 in the case of the strain P43 and ST439 in the case of the strain P69 (Table 5).

Based on the database of Pseudomonas aeruginosa MLST Database [24], these STs were previously identified in the cases of both the environmental and the clinical isolates of $P$. aeruginosa. The identified sequence type ST253 belongs to the well-revealed PA14 clonal complex and was previously detected in the case of strains originated from various samples such as soil [23], sputum of a CF patient [12], bronchial lavage, or urinary tract

Table 4. The detectable cell counts of microorganisms, hydrocarbon degrading bacteria and $P$. aeruginosa of environmental samples containing multidrug resistant $P$. aeruginosa strains

\begin{tabular}{ccccc}
\hline Origin, type of sample & $\begin{array}{c}\text { Microbial cell counts } \\
{\left[\mathrm{CFU} \times \mathrm{ml}^{-1}\right]}\end{array}$ & $\begin{array}{c}\text { Hydrocarbon } \\
\text { degrading bacteria** } \\
{\left[\mathrm{MPN} \times \mathrm{ml}^{-1}\right]}\end{array}$ & $\begin{array}{c}\text { P. aeruginosa cell counts } \\
{\left[\mathrm{MPN} \times \mathrm{ml}^{-1}\right]}\end{array}$ & $\begin{array}{c}\text { Designation } \\
\text { of the isolated } \\
\text { P. aeruginosa strains }\end{array}$ \\
\hline Ópusztaszer, groundwater* & $9.3 \times 10^{3}$ & $1.1 \times 10^{2}$ & $2.90 \times 10^{1}$ & $\mathrm{P} 43^{*}$ \\
Nagyszénás, groundwater* & $1.5 \times 10^{7}$ & $1.5 \times 10^{6}$ & $1.16 \times 10^{3}$ & P69* \\
\hline
\end{tabular}

CFU - colony forming units; MPN - most probable number.

* Environmental sites and their isolates were included in a previous study [9].

** Hydrocarbon degrading bacteria were enumerated in Bushnell-Haas mineral medium with MPN method [35]. 


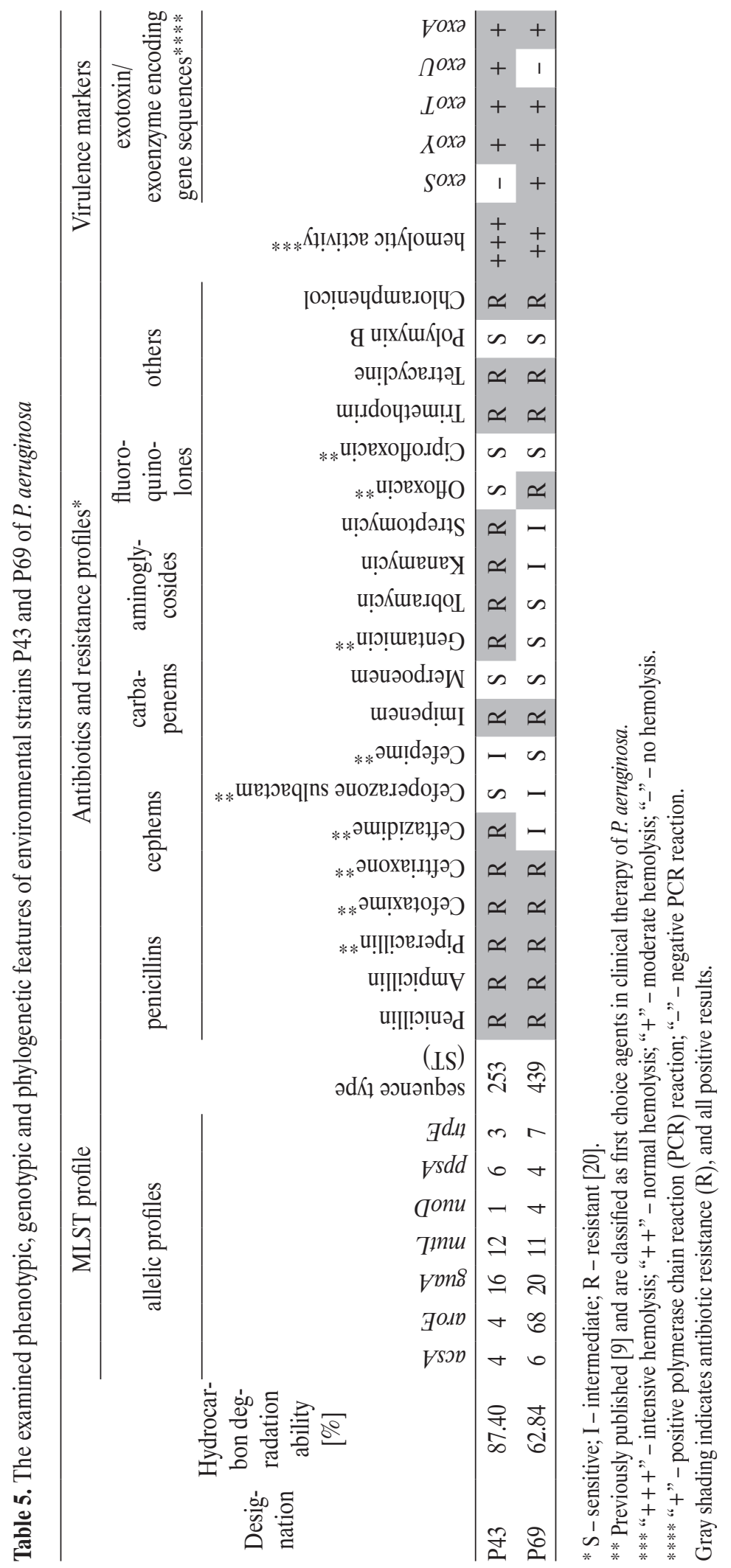


infection. The geographic locations of these detections were completely different, since 4 out of the above mentioned sources were located in Europe (UK, Hungary, and Poland), while one of the isolated strains originated from Australia. Therefore, it is presumed that $\mathrm{P} 43$ is a member of a globally successful clonal complex of $P$. aeruginosa. The identified sequence type ST439 of strain P69 was previously described in samples originated from a Cystic Fibrosis Clinic, France.

The neighbor-joining analysis of the detected STs (generated with the European Molecular Biology Open Software Suite (EMBOSS) web tool of Pseudomonas aeruginosa MLST Database [24] with STs of $\geq 4$ matches) are summarized in the Figure 1 and the Figure 2. The analysis of the available background information of STs with the closest relation to strain P43 (ST253) shows that the neighboring strains of ST828 are originated from CF patients, while others, such as ST109, ST107 and ST104 related to $\mathrm{O} 10$ or $\mathrm{O} 11$ serotype, out of which $\mathrm{O} 11$ is described as dominant among clinical isolates of $P$. aeruginosa [36]. In the case of P69 (ST439) the available information is limited, but the isolated strains with the same ST suggest

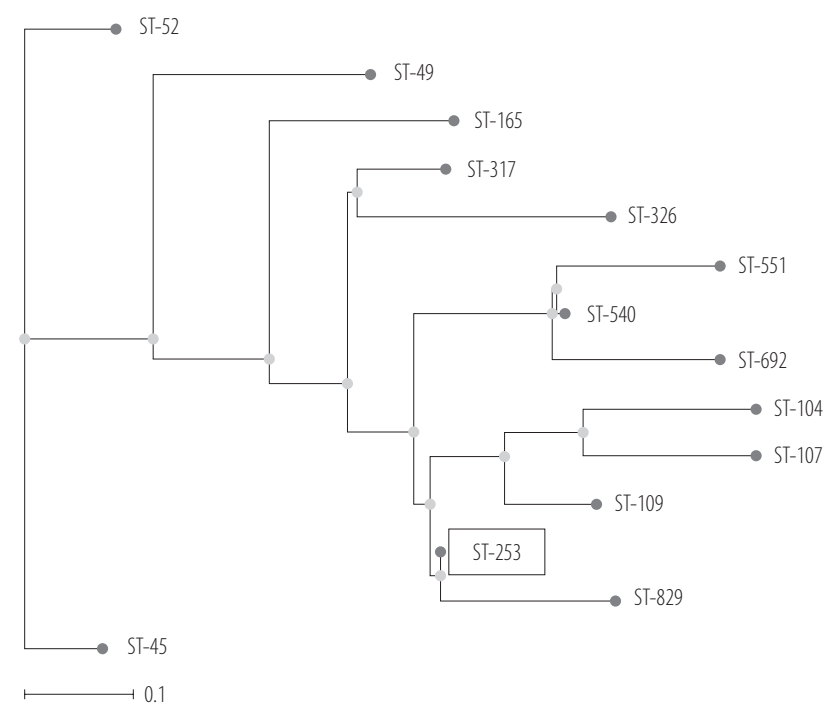

Fig. 1. The position of ST253 (strain P43) on the phylogenetic tree of $P$. aeruginosa multilocus sequence types (MLSTs)

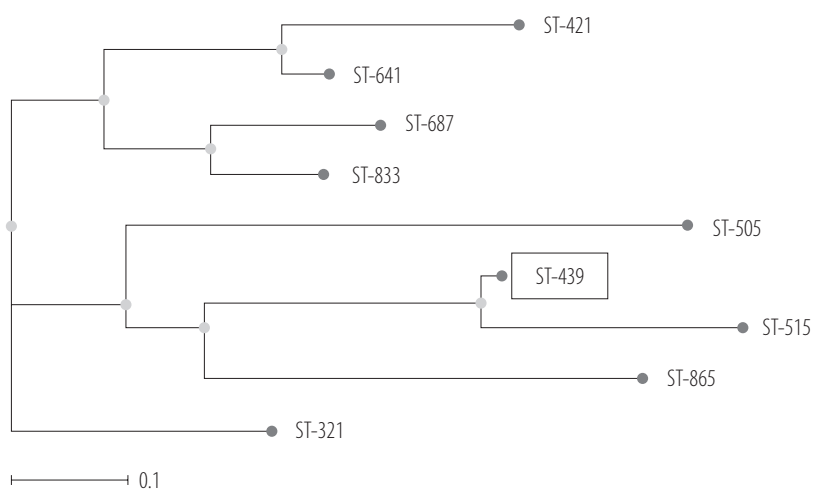

Fig. 2. The position of ST439 (strain P69) on the phylogenetic tree of $P$. aeruginosa multilocus sequence types (MLSTs)

that these strains are capable of playing a role in infection of $\mathrm{CF}$ patients.

\section{Antibiotic resistance investigations}

Based on our antibiotic resistance investigations, the isolated environmental strains of $P$. aeruginosa show antibiotic resistance against Penicillins and third generation Cephalosporins of Cephems (cefotaxime, ceftriaxone, ceftazidime) with the exception of the combination of cefoperazone-sulbactam and the fourth generation Cephalosporin (cefepime). Aminoglycosides were completely ineffective against the strain P43, but they were effective in the case of the strain P69. Among Fluoroquinolones, the antibiotic resistance was detectable only in one case (P69 against ofloxacin). Other antibiotics, such as the examined Folate (trimethoprim), Phenicol (chloramphenicol), Lipopeptide (polymyxin B) and Tetracycline (tetracycline) antibiotic agents had no effect on the examined strains except for polymyxin B. Based on these results, the multidrug resistant features can be confirmed both in the case of P43 and P69 and the multiple resistance mechanisms are presumed.

\section{Virulence markers investigations}

Based on virulence markers assay, both of the examined strains show hemolytic activity, and carry gene sequences encoding the production of toxic proteins exo $A$, exoY, and 
exoT. A different pattern was obtained in the presence and absence of exo $U$ and exo $S$ genes; exo $U$ gene sequence was detectable in the case of strain P43, while exoS gene sequence was identified in the case of strain P69. Based on scientific literature, the expression of effector protein exoS is associated with colonization and invasive features, while exo $U$ is related to increased virulence and cytotoxicity [37]. Therefore, strain P43 can be classified as cytotoxic isolate, while P69 can bring into connection with invasive features.

\section{In vivo virulence investigations}

Based on the agar plate count method, the formed groups of test animals (P43/1, P43/2, P43/3 and P69/1, P69/2, $\mathrm{P} 69 / 3$ ) were inoculated with the serially diluted bacterial suspensions of strains P43 and P69. The relevant doses are shown in the Table 6.

The short and long term changes in weight values are summarized in the Table 6 and the Figure 3, where experimental groups $\mathrm{P} 43 / 3$ and $\mathrm{P} 69 / 3$ are not involved since due to the $100 \%$ mortality of test animals in $24 \mathrm{~h}$.

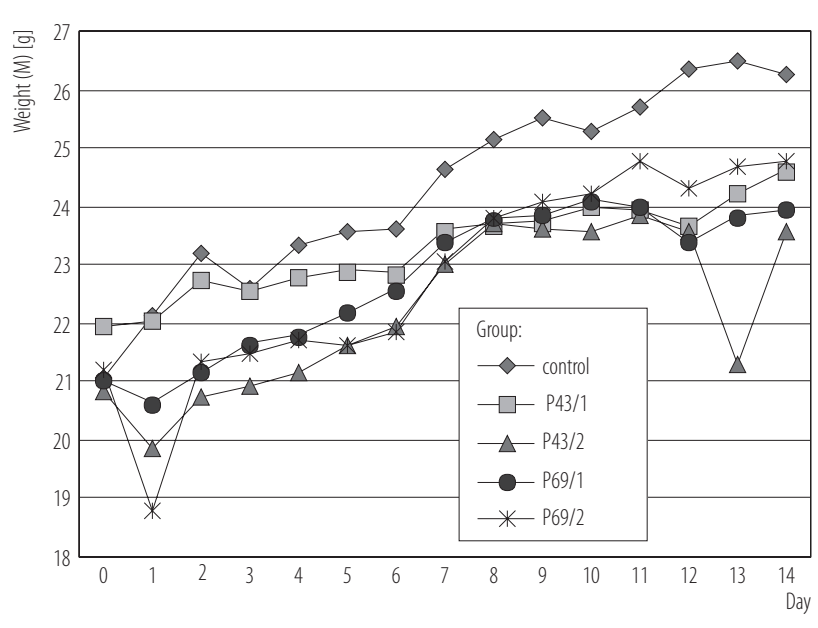

Fig. 3. Time dependent changes in the mean values of weight of mice groups treated with different intraperitoneal doses of strains of $P$. areuginosa

As it can be seen, the injection of bacterial suspensions had serious and concentration dependent effects on body weight directly following the first $24 \mathrm{~h}$ period that can be attributed to a decreased intake of food. Further weighing showed a steady (4.6-16.35\%) lag in body weights (Figure 3 ) in comparison with the control group that can be

Table 6. Details and results of the applied mouse model for testing virulence of P. aeruginosa strains P43 and P69

\begin{tabular}{|c|c|c|c|c|c|c|}
\hline \multirow[t]{2}{*}{ Test group } & \multirow{2}{*}{$\begin{array}{l}\text { Bacterial cell } \\
\text { counts } \\
{\left[\mathrm{CFU} \times \mathrm{ml}^{-1}\right]}\end{array}$} & \multicolumn{2}{|c|}{$\begin{array}{c}\text { Changes in mean weights } \\
\text { of groups } \\
{[\%]}\end{array}$} & \multirow{2}{*}{$\begin{array}{l}\text { Clinical symptoms* } \\
\text { or macroscopic changes of organs** } \\
\text { (total/cases) } \\
{[\mathrm{n}]}\end{array}$} & \multirow[t]{2}{*}{$\begin{array}{l}\text { Lethality } \\
{[\% / 24 \mathrm{~h}]}\end{array}$} & \multirow[t]{2}{*}{$\begin{array}{c}\mathrm{LD}_{50} \text { values } \\
{[\mathrm{CFU}]}\end{array}$} \\
\hline & & in $24 \mathrm{~h}$ & in 14 days & & & \\
\hline Control & n.a. & +5.03 & +24.57 & n.a. & 0.0 & n.a. \\
\hline P43 & & & & & & $5.37 \times 10^{5}$ \\
\hline $\mathrm{P} 43 / 1$ & $1.16 \times 10^{3}$ & +0.36 & +12.11 & $5 / 2$ & 0.0 & \\
\hline $\mathrm{P} 43 / 2$ & $1.16 \times 10^{5}$ & -4.71 & +13.16 & $5 / 2$ & 0.0 & \\
\hline $\mathrm{P} 43 / 3$ & $1.16 \times 10^{7}$ & n.a. & n.a. & $5 / 5$ & 100.0 & \\
\hline P69 & & & & & & $7.07 \times 10^{5}$ \\
\hline P69/1 & $5.70 \times 10^{3}$ & -1.90 & +13.99 & $5 / 0$ & 0.0 & \\
\hline $\mathrm{P} 69 / 2$ & $5.70 \times 10^{5}$ & -11.32 & +16.82 & $5 / 1$ & 0.0 & \\
\hline $\mathrm{P} 69 / 3$ & $5.70 \times 10^{7}$ & n.a. & n.a. & $5 / 5$ & 100.0 & \\
\hline
\end{tabular}

* General status, behavior, movement coordination, disorders in nervous system.

** Gastro-intestinal tract, cardiovascular system, lungs, liver, lien or kidneys.

$\mathrm{LD}_{50}$ - lethal dose, 50\%; n.a. - non-applicable. 
attributed to the long-term negative effects of infectious materials on general status of test animals.

Based on necropsy, the typical clinical symptom of bacterial injection was splenomegaly detectable in $35 \%$ of the examined test animals. Septicaemia was established in the case of test animals that perished before the end of the 14-day experiment (members of groups P43/3, P69/3 and P69/2), since infectious material was re-isolable from their blood culture. The heart puncture of surviving individuals of group P43/1, P43/3, P69/1 and P69/2 did not show the signs of septicaemia.

The rates of lethality in correlation with infectious doses led to the determination of $\mathrm{LD}_{50}$ values of $5.37 \times 10^{5} \mathrm{CFU}$ (strain P43) and $7.07 \times 10^{5} \mathrm{CFU}$ (strain P69), respectively.

\section{DISCUSSION}

Based on our multiplex analysis of 2 environmental originating strains of $P$. aeruginosa (P43 and P69), a complex dataset became available with regard to phylogenetic relations, antibiotic resistance and virulence features, hydrocarbon degrading ability and genotypes. This complex estimation follows the suggested trends for the examination of opportunistic species such as P. aeruginosa [13] and may fill in the gap experienced in the field of environmentally originated strains.

The multilocus sequence typing of the examined isolates led to the detection of 2 known STs (ST253 and ST439), which have had previously been identified among strains, both in clinical and environmental surroundings [23]. Some of the isolated strains related to these phylogenetic categories had notable influence upon the infection of CF patients [12]. This strong, phylogenetic relation corroborates the connection between the environmental strains and those that have importance to the infection of CF patients. Virulence investigations show that the examined strains of environmental origin carry notable virulence markers such as gene sequences exo $A$, exoT, exo $Y$ and exoU/exoS, which are the major contributors of infectious diseases caused by $P$. aeruginosa species [38]. In our work, the presence of the exoS gene, a main contributor of successful colonization of CF lungs [13], was identified in the case of environmental strain P69, while exoU, a cytotoxic factor was identified in the genome of strain P43. The detection of different exoU/exoS gene profiles suggests that both the invasive (exoS carrying) and the cytotoxic (exoU holder) isolates are able to find adequate circumstances in hydrocarbon contaminated natural environments. Further investigation is required to clarify the environmental frequency of these different gene profiles of P. aeruginosa. Regarding the direct virulence features, even taking into consideration the differences in exoU/exoS gene profiles, and with regard to the infectious doses $\left(10^{2}-10^{8}\right.$ cells $)$ of $P$. aeruginosa species determined by scientific reports $[39,40]$, we can conclude that intraperitoneal injection of environmental strains P43 and P69 can cause lethal disease and septicaemia in relatively low cell counts $\left(\mathrm{LD}_{50}\right.$ value: $\left.10^{5}\right)$. The macroscopic study of organs following the necropsy suggests that infectious material P43, carrying the cytotoxic factor exoU, has greater cell and tissue damaging influence than the invasive exoS carrying strain (P69). This suggestion is confirmed also by means of greater lethal doses of strain P43.

The direct human health concerns of the determined $\mathrm{LD}_{50}$ values can be evaluated with the overview of detectable bacterial cell counts of $P$. aeruginosa both in clinical and environmental surroundings. The available information suggests that the examined species is able to reach the determined $\mathrm{LD}_{50}$ level, not only in clinical circumstances [41], but in natural environments, too. To give examples, the verified cell counts of $P$. aeruginosa species in hydrocarbon contaminated sites have been up to $10^{4} \mathrm{MPN} \times \mathrm{g}^{-1}$ soil or $\mathrm{ml}^{-1}$ groundwater [9], in composts it can range $10^{0}-10^{6} \mathrm{MPN} \times \mathrm{g}^{-1}$ [42], and it is also notable in natural and agricultural soils [43,44], or vegetables $\left(5 \times 10^{3} \mathrm{CFU} \times \mathrm{g}^{-1}\right)[45,46]$.

Considering the typical pathways of environmental and occupational exposures to microorganisms, such as 
inhalation, swallowing or the injury of physical barriers, and with regards to special circumstances of hydrocarbon contaminated sites, where the aim is to increase the populations of hydrocarbon degrading microorganisms to levels $>10^{5} \mathrm{CFU} \times \mathrm{g}^{-1}$ cells in dry solids [47], the presence or direct application of $P$. aeruginosa strains for bioremediation purposes, with the characteristic features discussed above, pose a considerable health risk.

\section{CONCLUSIONS}

Based on our multiplex analysis of several features, the investigated environmental strains of $P$. aeruginosa are not just theoretically able to cause disease: MLST profiles of environmental isolates $\mathrm{P} 43$ and $\mathrm{P} 69$ are strongly related to those that play roles in infection (mainly of cystic fibrosis patients), environmental strains commonly carry gene sequences that are important in pathogenesis, cause notable lethality in the applied mouse model, moreover, retain their hydrocarbon degrading ability.

In summary, we can conclude that the human health hazard of a $P$. aeruginosa strain cannot be determined based on the knowledge of clinical or environmental source. The practice of isolating microorganisms from environmental sources for bioremediation purposes solely on the basis of their hydrocarbon decomposing activity is not a proper method to ensure the environmental and occupational safety of biotechnological processes. The parallel investigation on further clinically important features of the applied microorganisms and the exclusion of opportunistic species constitutes an urgent issue of environmental, occupational and public health.

\section{REFERENCES}

1. Richmond RH. Environmental protection: Applying the precautionary principle and proactive regulation to biotechnology. Trends Biotechnol. 2008;26(8):460-7, http://dx.doi. org/10.1016/j.tibtech.2008.05.003.
2. Kalin M, Wheeler WN, Meinrath G. The removal of uranium from mining waste water using algal/microbial biomass. J Environ Radioact. 2005;78(2):151-77, http://dx.doi.org/10.1016/ j.jenvrad.2004.05.002.

3. Das K, Mukherjee AK. Crude petroleum-oil biodegradation efficiency of Bacillus subtilis and Pseudomonas aeruginosa strains isolated from petroleum-oil contaminated soil from North-East India. Bioresour Technol. 2007;98(7):1339-45, http://dx.doi.org/10.1016/j.biortech.2006.05.032.

4. Mesaros N, Nordmann P, Plésiat P, Roussel-Delvallez M, van Eldere J, Glupczynski Y, et al. Pseudomonas aeruginosa: Resistance and therapeutic options at the turn of the new millennium. Clin Microbiol Infect. 2007;13(6):560-78, http:// dx.doi.org/10.1111/j.1469-0691.2007.01681.x.

5. Miliani K, l'Hériteau F, Lacavé L, Carbonne A, Astagneau P. on behalf of the Antimicrobial Surveillance Network Study Group. Imipenem and ciprofloxacin consumption as factors associated with high incidence rates of resistant Pseudomonas aeruginosa in hospitals in northern France. J Hosp Infect. 2011; 77(4):343-7, http://dx.doi.org/10.1016/j.jhin.2010.11.024.

6. Ridgway HF, Safarik J, Phipps D, Carl P, Clark D. Identification and catabolic activity of well-derived gasoline-degrading bacteria from a contaminated aquifer. Appl Environ Microbiol. 1990;56:3565-75.

7. Bondarenko O, Rahman PK, Rahman TJ, Kahru A, Ivask A. Effects of rhamnolipids from Pseudomonas aeruginosa DS10-129 on luminescent bacteria: Toxicity and modulation of cadmium bioavailability. Microb Ecol. 2010;59(3):588600, http://dx.doi.org/10.1007/s00248-009-9626-5.

8. Fu H, Zeng G, Zhong H, Yuan X, Wang W, Huang G, et al. Effects of rhamnolipid on degradation of granular organic substrate from kitchen waste by a Pseudomonas aeruginosa strain. Colloids Surf B Biointerfaces. 2007;58(2):91-7, http:// dx.doi.org/10.1016/j.colsurfb.2007.02.012.

9. Kaszab E, Kriszt B, Atzél B, Szabó G, Szabó I, Harkai P, et al. The occurrence of multidrug resistant Pseudomonas aeruginosa on hydrocarbon contaminated sites. Microb Ecol. 2010;59(1):37-45, http://dx.doi.org/10.1007/s00248-009-9551-7. 
10. De Kievit TR. Quorum sensing in Pseudomonas aeruginosa biofilms. Environ Microbiol. 2009;11(2):279-88, http:// dx.doi.org/10.1111/j.1462-2920.2008.01792.x.

11. Alonso A, Rojo F, Martínez JL. Environmental and clinical isolates of Pseudomonas aeruginosa show pathogenic and biodegradative properties irrespective of their origin. Environ Microbiol. 1999;1(5):421-30, http://dx.doi.org/10.1046/ j.1462-2920.1999.00052.x.

12. Kidd TJ, Rainey PB, Ramsay KA, Grimwood K, Wainwright CE, Bell SC. Multilocus sequence typing (MLST) of Pseudomonas aeruginosa collected from different ecological niches. J Cyst Fibros. 2010;9 Suppl. 1:S30, http://dx.doi.org/ 10.1016/S1569-1993(10)60114-2.

13. Pirnay J-P, Bilocq F, Pot B, Cornelis P, Zizi M, van Eldere J, et al. Pseudomonas aeruginosa population structure revised. PLoS One. 2009;4(11):e7740, http://dx.doi. org/10.1371/journal.pone.0007740.

14. Arancibia F, Bauer TT, Ewig S, Mensa J, Gonzalez J, Niederman MS, et al. Community-acquired pneumonia due to Gram-negative bacteria and Pseudomonas aeruginosa: Incidence, risk, and prognosis. Arch Intern Med. 2002;162(16):1849-58, http://dx.doi.org/10.1001/archinte.162. 16.1849 .

15. MSZ 21464:1998. [Sampling of groundwaters]. Budapest: Hungarian Standards Institution; 1998. Hungarian.

16. MSZ 21470-1:1998. [Environmental protection. Testing of soils. Sampling]. Budapest: Hungarian Standards Institution; 1998. Hungarian.

17. MSZ EN ISO 9377-2:2001. [Water quality - Determination of hydrocarbon oil index - Part 2: Method using solvent extraction and gas chromatography]. Budapest: Hungarian Standards Institution; 2001. Hungarian.

18. MSZ 21470-77:1988. [Environmental protection. Testing of soils. Microbiological test]. Budapest: Hungarian Standards Institution; 1988. Hungarian.

19. Spilker T, Coenye T, Vandamme P, LiPuma JJ. PCR-based assay for differentiation of Pseudomonas aeruginosa from other Pseudomonas species recovered from cystic fibrosis patients. J Clin Microbiol. 2004;42(5):2074-9, http://dx.doi. org/10.1128/JCM.42.5.2074-2079.2004.

20. Clinical and Laboratory Standards Institute. Methods for dilution antimicrobial susceptibility tests for bacteria that grow aerobically; approved standard - Seventh edition. CLSI document M7-A7. Wayne (PA): The Institute; 2006. p. 1-64.

21. Clinical and Laboratory Standards Institute. Performance standards for antimicrobial susceptibility testing; seventeenth informational supplement. CLSI document M100S17. Wayne (PA): The Institute; 2007. p. 1-182.

22. Draghi DC, Jones ME, Sahm DF, Tillotson GS. Geographically-based evaluation of multidrug resistance trends among Streptococcus pneumoniae in the USA: Findings of the FAST surveillance initiative (2003-2004). Int J Antimicrob Agents. 2006;28(6):525-31, http://dx.doi.org/http:// dx.doi.org/10.1016/j.ijantimicag.2006.09.002.

23. Curran B, Jonas D, Grundmann H, Pitt T, Dowson CG. Development of a multilocus sequence typing scheme for the opportunistic pathogen Pseudomonas aeruginosa. J Clin Microbiol. 2004;42(12):5644-9, http://dx.doi.org/10.1128/ JCM.42.12.5644-5649.2004.

24. Pseudomonas aeruginosa MLST Database [Internet]. London: Wellcome Trust; c2010 [cited 2015 Apr 12]. Available from: http://pubmlst.org/paeruginosa.

25. Jolley KA, Chan M-S, Maiden MCJ. MlstdbNet - Distributed multi-locus sequence typing (MLST) databases. BMC Bioinformatics. 2004;5:86, http://dx.doi.org/10.1186/14712105-5-86.

26. Winstanley C, Kaye SB, Neal TJ, Chilton HJ, Miksch S, Hart CA, et al. Genotypic and phenotypic characteristics of Pseudomonas aeruginosa isolates associated with ulcerative keratitis. J Med Microbiol. 2005;54(Pt 6):519-26, http:// dx.doi.org/10.1099/jmm.0.46005-0.

27. Atzél B, Szoboszlay S, Mikuska Zs, Kriszt B. Comparison of phenotypic and genotypic methods for the detection of environmental isolates of Pseudomonas aeruginosa. Int J Hyg Environ Health. 2007;211(1-2):143-55, http:/dx.doi.org/ 10.1016/j.ijheh.2007.04.001. 
28. Ajayi T, Allmond LR, Sawa T, Wiener-Kronish JP. Single-nucleotide-polymorphism mapping of the Pseudomonas aeruginosa type III secretion toxins for development of a diagnostic multiplex PCR system. J Clin Microbiol. 2003;41(8):352631, http://dx.doi.org/10.1128/JCM.41.8.3526-3531.2003.

29. Organisation for Economic Co-operation and Development. Guidance document on the recognition, assessment, and use of clinical signs as humane endpoints for experimental animals used in safety evaluation [Internet]. Paris: The Organization; 2000 [cited 2011 Dec 5]. Available from: https://ntp. niehs.nih.gov/iccvam/suppdocs/feddocs/oecd/oecd_gd19.pdf.

30. Koh AY, Priebe GP, Pier GB. Virulence of Pseudomonas aeruginosa in a murine model of gastrointestinal colonization and dissemination in neutropenia. Infect Immun. 2005;73(4):2262-72, http://dx.doi.org/10.1128/IAI.73.4. 2262-2272.2005.

31. Tamura Y, Tanaka S. Effect of calcium chloride on experimental infection of mice with Pseudomonas aeruginosa. Infect Immun. 1985;48(3):648-51, http://iai.asm.org/content/48/3/648.long.

32. Murphey ED, Sherwood ER. Bacterial clearance and mortality are not improved by a combination of IL-10 neutralization and IFN- $\gamma$ administration in a murine model of postCLP immunosuppression. Shock. 2006;26(4):417-24, http:// dx.doi.org/10.1097/01.shk.0000226343.70904.4f.

33. Miller LC, Tainter ML. Estimation of $\mathrm{LD}_{50}$ and its error by means of log-probit graph paper. Proc Soc Exp Biol Med. 1944;57:261-4.

34. Kaszab E, Bedros JR, Szoboszlay S, Atzél B, Szabó I, Cserháti $\mathrm{M}$, et al. Problems with environmental safety on bioremediated sites. AARMS. 2006;5(3):383-97.

35. Bushnell CD, Haas HF. The utilization of certain hydrocarbons by microorganisms. J Bacteriol. 1941;41:654-73.

36. Poh CL, Yap EH, Tay L, Bergan T. Plasmid profiles compared with serotyping and pyocin typing for epidemiological surveillance of Pseudomonas aeruginosa. J Med Microbiol. 1988;25(2):109-14, http://dx.doi.org/10.1099/0022261525-2-109.
37. Fleiszig SM, Wiener-Kronish JP, Miyazaki H, Vallas V, Mostov KE, Kanada D, et al. Pseudomonas aeruginosamediated cytotoxicity and invasion correlate with distinct genotypes at the loci encoding exoenzyme S. Infect Immun. 1997;65(2):579-86.

38. Lin H-H, Huang S-P, Teng H-C, Ji D-D, Chen Y-S, Chen Y-L. Presence of the exoU gene of Pseudomonas aeruginosa is correlated with cytotoxicity in MDCK cells but not with colonization in BALB/c mice. J Clin Microbiol. 2006;44(12): 4596-7, http://dx.doi.org/10.1128/JCM.01531-06.

39. Fok N. Pseudomonas aeruginosa as a waterborne gastroenteritis pathogen. Environ Health Rev. 2005;49:121-30.

40. Lizewski S, Lundberg DS, Schurr MJ. The transcriptional regulator $\mathrm{AlgR}$ is essential for Pseudomonas aeruginosa pathogenesis. Infect Immunol. 2002;70(11):6083-93, http:// dx.doi.org/10.1128/IAI.70.11.6083-6093.2002.

41. Panagea S, Winstanley C, Washaw MJ, Ledson MJ, Har CA. Environmental contamination with an depidemic strain of Pseudomonas aeruginosa in a Liverpool cystic fibrosis centre, and study of its survival on dry surfaces. J Hosp Infect. 2005;59(2):102-9, http://dx.doi.org/10.1016/j.jhin.2004.09.018.

42. Kaszab E, Szoboszlay S, Dobolyi Cs, Háhn J, Pék N, Kriszt B. Antibiotic resistance profiles and virulence markers of Pseudomonas aeruginosa strains isolated from composts. Bioresour Technol. 2010;102(2):1543-8, http://dx.doi. org/10.1016/j.biortech.2010.08.027.

43. Ferguson MW, Maxwell JA, Vincent TS, da Silva J, Olson JC. Comparison of the exoS gene and protein expression in soil and clinical isolates of Pseudomonas aeruginosa. Infect Immun. 2001;69(4):2198-210, http://dx.doi.org/10.1128/ IAI.69.4.2198-2210.2001.

44. Green SK, Schroth MN, Cho JJ, Kominos SD, VitanzaJack VB. Agricultural plants and soil as a reservoir for Pseudomonas aeruginosa. Appl Microbiol. 1974;28:987-91. Available from: http://www.ncbi.nlm.nih.gov/pmc/articles/ PMC186868/.

45. Kominos SD, Copeland CE, Grosiak B, Postic B. Introduction of Pseudomonas aeruginosa into a hospital via vege- 
tables. Appl Microbiol. 1972;24(4):567-70. Available from: http://www.ncbi.nlm.nih.gov/pmc/articles/PMC380614/.

46. Shooter RA, Cooke EM, Faiers MC, Breaden AL, O'Farrell SM. Isolation of Escherichia coli, Pseudomonas aeruginosa and Klebsiella from food in hospitals, canteens, and schools. Lancet. 1971;298(7721):390-2, http://dx.doi. org/10.1016/S0140-6736(71)90111-5.
47. Weber WJ, Corseuil HX. Inoculation of contaminated subsurface soils with enriched indigenous microbes to enhance bioremediation rates. Water Res. 1994;28(6):1407-14, http:// dx.doi.org/10.1016/0043-1354(94)90308-5.

This work is available in Open Access model and licensed under a Creative Commons Attribution-NonCommercial 3.0 Poland License - http://creativecommons.org/ licenses/by-nc/3.0/pl/deed.en. 